\title{
Explaining trade in industrialized countries by country-specific human capital factor endowments
}

Citation for published version (APA):

Cörvers, F., \& de Grip, A. (1995). Explaining trade in industrialized countries by country-specific human capital factor endowments. Researchcentrum voor Onderwijs en Arbeidsmarkt, Faculteit der Economische Wetenschappen. ROA Research Memoranda No. 3E https://doi.org/10.26481/umaror.199503E

Document status and date:

Published: 01/01/1995

DOI:

10.26481/umaror.199503E

Document Version:

Publisher's PDF, also known as Version of record

\section{Please check the document version of this publication:}

- A submitted manuscript is the version of the article upon submission and before peer-review. There can be important differences between the submitted version and the official published version of record.

People interested in the research are advised to contact the author for the final version of the publication, or visit the DOI to the publisher's website.

- The final author version and the galley proof are versions of the publication after peer review.

- The final published version features the final layout of the paper including the volume, issue and page numbers.

Link to publication

\footnotetext{
General rights rights.

- You may freely distribute the URL identifying the publication in the public portal. please follow below link for the End User Agreement:

www.umlib.nl/taverne-license

Take down policy

If you believe that this document breaches copyright please contact us at:

repository@maastrichtuniversity.nl

providing details and we will investigate your claim.
}

Copyright and moral rights for the publications made accessible in the public portal are retained by the authors and/or other copyright owners and it is a condition of accessing publications that users recognise and abide by the legal requirements associated with these

- Users may download and print one copy of any publication from the public portal for the purpose of private study or research.

- You may not further distribute the material or use it for any profit-making activity or commercial gain

If the publication is distributed under the terms of Article $25 \mathrm{fa}$ of the Dutch Copyright Act, indicated by the "Taverne" license above, 


\section{Explaining Trade in Industrialized Countries by Country-specific Human Capital Factor Endowments}

Frank Cörvers and Andries de Grip

ROA-RM-1995/3E

Research Centre for Education and the Labour Market

Faculty of Economics and Business Administration University of Limburg

Maastricht, February 1995 


\section{CIP-GEGEVENS KONINKLIJKE BIBLIOTHEEK, DEN HAAG}

Cörvers, Frank

Explaining trade in industrialized countries by country-specific human capital factor endowments / Frank Cörvers and Andries de Grip. - Maastricht : Research Centre for Education and the Labour Market, Faculty of Economics and Business Administration, University of Limburg. - (ROA-RM-1995/3E)

Met lit. opg.

ISBN 90-5321-157-8

Trefw.: arbeidseconomie / human capital. 


\section{Contents}

Page

Abstract

i

1 Introduction 1

2 The Heckscher-Ohlin-Vanek model $\quad 5$

3 The empirical model 9

4 Hypotheses 13

5 Data preview 15

6 Estimation results 18

7 Conclusions 23

$\begin{array}{ll}\text { References } & 24\end{array}$

Appendix A Classification of ISIC sectors $\quad 29$

Appendix B Data sources 31

Appendix C Correlations between relative factor endowments 35

Appendix D RCAs of the resource-intensive category of economic sectors 37 


\begin{abstract}
This paper aims to explore the relevance of human capital factors for international trade flows. Within a Heckscher-Ohlin-Vanek model, apart from the traditional production factors labour and physical capital, both technological knowledge and human capital are considered to be relevant production factors that determine net trade flows between industrialized countries. The empirical analysis is applied to fourteen industrialized countries, distinguishing between labour-intensive, capital-intensive (both low/medium-tech and high-tech) and technology-intensive economic sectors. The empirical results of the study suggest that relative factor endowments at the country level can help to explain revealed comparative advantages at the sector level. In particular, an abundance of highly-skilled labour and technological knowledge in a country indicates a comparative advantage for the technology-intensive sectors, and a comparative disadvantage for the labour-intensive sectors. However, human capital factor endowments are in general found to be irrelevant for explaining revealed comparative advantages in the capital-intensive sectors.
\end{abstract}

We would like to thank Lex Borghans, Hans Heijke and Thomas Ziesemer for their helpful comments. 



\section{Introduction}

Leontief $(1953,1956)$ found that the U.S.A. imported capital-intensive goods and exported labour-intensive goods in 1947. This is contrary to the expectations of the HeckscherOhlin model, as the U.S.A. was relatively well-endowed with capital at that time. Leontief's empirical refutation of the Heckscher-Ohlin theorem became known as the 'Leontief paradox'. Since then, much more empirical research has been carried out which has provided evidence of the Leontief paradox. Baldwin (1971) offered a survey of several explanations for the paradox. One explanation focuses on the neglect of human capital (skilled labour). Leontief himself suggested that the reason for the paradox may be that the U.S.A. was relatively well-endowed with human capital. Others, such as Keesing (1966, 1968), Waehrer (1968), Branson and Monoyios (1977), and Stern and Maskus (1981), investigated the relationship between the structure of foreign trade and three production factors: physical capital, skilled labour and unskilled labour. Although these studies showed the relevance of human capital for an explanation of international trade patterns, they had two shortcomings: firstly, the specification of the model, and secondly, the failure to distinguish between different human capital factors.

As to the first shortcoming, the importance of a well-specified model is emphasized in e.g. Leamer $(1980,1992)$ and Leamer and Bowen (1981). They show that the trade performance of an economic sector is independent on the factor intensities of that particular sector. Rather, they point to its dependence on the relative abundance or scarcity of countries' factor endowments. This can be demonstrated by the Heckscher-Ohlin-Vanek (HOV) model (Vanek, 1968, Leamer, 1980, Leamer and Bowen, 1981, Deardorff, 1982), which is a factor endowments model akin to the traditional Heckscher-Ohlin model. According to the Heckscher-Ohlin-Vanek theorem, countries that have relatively large stocks of a particular factor endowment, for example human capital, will export the services of human capital. Those services are embodied in export commodities that make intensive use of human capital factors. However, in recent years empirical research on international trade flows has cast considerable doubt on the explanatory power of the Heckscher-Ohlin-Vanek model. ${ }^{1}$ Empirical studies show poor results if, in accordance with the HOV model, net trade flows at sector level are considered as flows of factor services that can be explained by countries' relative factor endowments. Bowen and Sveikauskas (1992, p. 619) conclude that "our results emphasize the importance of further work to determine exactly which assumptions are central in the rejection of the HOV factor abundance model." In particular the assumptions of similar input-output coefficients and

1. See for example Bowen, Leamer and Sveikauskas (1987) and Bowen and Sveikauskas (1992). 
factor price equalization across countries may be crucial for the rejection of the HOV model. However, these assumptions of the HOV model ${ }^{2}$ are more valid for a group of industrialized countries than for a mixed group of industrialized and developing countries. $^{3}$

Thus the HOV model might usefully be applied to a group of industrialized countries, although Helpman (1981), Deardorff (1984) and Krugman and Obstfeld (1991) remark that factor endowment models such as the HOV model should be used to explain interindustry trade between countries that differ relatively much in their factor endowments, for example between industrialized and developing countries. ${ }^{4}$ Moreover, they argue that trade models assuming economies of scale and product differentiation are best suited to explain intra-industry trade between industrialized countries. ${ }^{5}$ However, intra-industry trade models explain only the amount of trade between countries, whereas the HOV model has the potential to explain the direction of net trade flows (see Helpman, 1981, and Krugman and Obstfeld, 1991). Net trade flows are in particular important, since they determine the surplus or shortage in the trade balance, which is an important item in the trade negotiations between the United States, Japan and the European Union. Furthermore, about $40 \%$ of total trade in industrialized countries is still inter-industry trade (OECD, 1987). ${ }^{6}$ As for other assumptions of the HOV model, Leamer (1984) concludes that, if the assumptions with regard to trade impediments, international factor mobility, non-traded and intermediate goods, transportation costs, factor market distortions and consumer preference dissimilarities are not fulfilled, outcomes from the HOV model are not seriously affected. ${ }^{7}$

As to the second shortcoming, Wood (1994) points to the relevance of human capital, because human capital, in contrast to physical capital, is internationally immobile and therefore very relevant for explaining trade flows. Wood (1994) argues that correctly

2. Deardorff (1982) shows that if these assumptions are both met, factor intensity reversals cannot occur.

3. Moreover, generalizations of the HOV theorem without assuming factor price equalization are found in Brecher and Choudhri (1982), Deardorff (1982) and Helpman (1984).

4. Ethier (1982), however, shows that intra-industry trade, like inter-industry trade, may have a factor endowment basis.

5. We are, however, aware of other approaches to explaining international trade flows, such as technology gap models, demand oriented models and endogenous growth models. For overviews see Deardorff (1984) and Dosi, Pavitt and Soete (1990).

6. Inter-industry trade can be measured by the industry's absolute value of net exports expressed as a percentage of the industry's total trade (i.e. sum of exports and imports).

7. Moreover, the results of the HOV model are less distorted by trade barriers now than they once were, as the barriers are gradually broken down by free trade agreements. 
specified factor endowments models should exclude physical capital, due to the international mobility of flows of finance between countries, which, according to Wood, is an important reason for the failure of the HOV model to explain trade flows in the empirical studies mentioned above. However we will not follow Wood in this respect, since we regard physical capital as a stock of capital goods rather than as a flow of finance. Moreover, there are good reasons to assume that both human and physical capital factor endowments are dependent on country-specific circumstances, such as the educational system or government policy with regard to the investment climate (e.g. investment tax credits and the tax system). Those institutional aspects may determine the national abundance or scarcity of factor endowments. Therefore this paper uses the HOV model to attempt to explain the trade performance of economic sectors, distinguishing the factor endowments of labour, human capital, physical capital and technological knowledge at the country level. Our analysis focuses particularly on the relevance of these production factors. The empirical analysis is applied to fourteen industrialized countries (eleven European Union member states, Japan, Canada and the USA). We will distinguish between labour-intensive, capital-intensive (both low/medium-tech and high-tech) and technology-intensive economic sectors. Moreover, for each of these categories of economic sectors, we will estimate the relevance of the factor endowments mentioned above, first without distinguishing between factor endowments of human capital at various level, and then with this distinction.

In this paper we do not measure human capital from discounted sector-wage differentials (see e.g. Branson and Monoyios, 1977 and Stern and Maskus, 1981). Nor do we measure it for occupational categories of workers (see e.g. Baldwin, 1971, Leamer, 1984, and Bowen, Leamer and Sveikauskas, 1987). We do, however, distinguish human capital factor endowments at three levels, represented by the proportion of low skilled, intermediate skilled and highly-skilled workers in a country's labour force. These three levels of education allow for the different impact of the supply of intermediate skilled 'craft' workers and highly-skilled 'professionals'. ${ }^{8}$ Campbell and Warner (1991) point out that the lack of an adequate supply of intermediate skilled workers in Britain contrasts with the relative strength of the West German intermediate skill base, which may be crucial in explaining the relative performance of the British and West German engineering industries. On the other hand, Daly (1986), examining the relative productivity of U.S. and British industries, could not find any positive effect due to the share of intermediate skilled workers, but did find a positive and significant effect from the share of highly-skilled workers. In this paper the shares of low skilled, intermediate skilled and highly-skilled

8. See for example Prais (1981) and Lindley (1991), who state that the distinction between these two skill groups may be very important for determining total productivity. 
workers in a country's labour force are assumed to represent the relative factor endowments of the various kinds of human capital. The relative abundance of these groups of workers contribute, according to the HOV model, to the trade performance of the economic sectors that make intensive use of these human capital factors. This implies that low skilled labour is expected to be used relatively intensively in labour-intensive sectors, whereas highly-skilled labour is expected to be used relatively intensively in technology-intensive sectors. For intermediate skilled labour, the expectations are less evident, although such labour may be used relatively intensively, along with physical capital, in the capital-intensive sectors.

Furthermore, Daniels (1993) found evidence for the importance of national differences in technological capabilities as a determinant of the trade performance of technologyintensive sectors, whereas human capital variables had little explanatory power. However, a country's investments in technological knowledge, which are often measured by its research and development (R\&D) intensity (i.e. $R \& D$ expenditures divided by GDP) can be partly interpreted as an investment in human capital, ${ }^{9}$ since R\&D expenditures consist largely of wage costs for highly-educated R\&D workers. ${ }^{10}$ These R\&D workers embody an important part of the country's stock of technological knowledge. ${ }^{11}$ Furthermore, workers participating in R\&D activities often have an education in natural sciences or engineering, which may imply that, in measuring investments in technological knowledge, it is not only the level of education that matters, but also the type. Investments in technological knowledge can be expected to have a positive impact on the trade performance of both capital-intensive high-tech sectors and technology-intensive sectors. Notice that we assume that the differing levels of technological knowledge between countries influence the net exports per sector, just like differences in other factor endowments.

Following Leamer (1984), we will regress the net exports of sectors on the factor endowments of countries. There are, however, some important differences between our empirical study and Leamer's, which may improve the results of our empirical analysis. Firstly, we have used a sample of 14 industrialized countries, which are presumably more equal in their production functions (i.e. input-output coefficients) than Leamer's sample of 60 countries, which contains both developed and underdeveloped countries. Secondly, Leamer measures human capital and technological inputs by distinguishing occupational

9. In section $V$, the importation of technological knowledge is also included in the empirical analysis.

10. The wage costs of R\&D workers comprise between 80 and $90 \%$ of total R\&D expenditures in most industrialized countries (see appendix B for data sources on technological knowledge).

11. Lucas (1988) also uses the notion that (technological) knowledge is embodied in human beings and is passed on to younger generations. See also Wood (1994). 
categories. The numbers of professional, technical and related workers are assumed to represent technological inputs, while he approximates human capital inputs by the number of literate nonprofessional workers. Instead, we consider differences between countries with regard to the levels of education and technological knowledge. This is in line with Wood (1994), who argues that the occupational categories in empirical studies, such as Leamer (1984) and Bowen, Leamer and Sveikauskas (1987), are based on the type of work done rather than on the level of education. Furthermore, since we have only industrialized countries in our sample, it is probably not relevant to distinguish, as Leamer (1984) does, the number of illiterate workers. Thirdly, Leamer (1984) constructs trade aggregates for his empirical analysis, whereas we distinguish between resource-intensive, labour-intensive, capital-intensive and technology-intensive sectors. ${ }^{12}$ Moreover, the group of capital-intensive sectors is differentiated into low/medium-tech sectors on the one hand and high-tech sectors on the other hand. ${ }^{13}$ Fourthly, in contrast to Leamer (1984), we develop explicit hypotheses with regard to the impact of the relative factor endowments of labour, human capital, technological knowledge and physical capital on the trade performance of sectors. The hypotheses with regard to the human capital factor endowments are founded on the complementarities between physical capital and human capital on the one hand, and technology and human capital on the other hand (see above). ${ }^{14}$ Fifthly, and again in contrast to Leamer (1984), we have scaled the variables in our analysis. This paper will discuss the relevance and method of scaling.

The structure of the remainder of the paper is as follows. Section 2 presents the HOV model, and section 3 the empirical model. Section 4 develops the hypotheses to be tested, and section 5 briefly discusses some features of the data. Section 6 presents the final results of the empirical analysis. In this section the indicators of revealed comparative advantage of the 14 industrialized countries will be regressed on the relative factor endowments of labour, human capital, technological knowledge and physical capital. The regression method used is the ordinary least squares method (OLS). Section 7 summarizes the main conclusions of the paper.

\section{The Heckscher-Ohlin-Vanek model}

This section presents the Heckscher-Ohlin-Vanek (HOV) model (Vanek, 1968, Leamer, 1980, Leamer and Bowen, 1981, Deardorff, 1982). The HOV model is also known as the

12. For a similar classification, see OECD (1987).

13. See OECD (1986) and Verspagen (1993).

14. See also Wood (1994). 
factor content version of the more familiar Heckscher-Ohlin model. The HOV model accentuates the role of factor services. In this paper, the factor services stand for the input requirements of the factors of production that were needed to produce the goods traded. One of the theorems following from the HOV model, the Heckscher-Ohlin-Vanek theorem, says that countries tend to export the factor services of their relatively abundant production factors and tend to import the factor services of their relatively scarce production factors. ${ }^{15}$ It emphasizes that factor services are exchanged through trade. The traded goods that embody or contain the services of the production factors merely conduct that exchange.

The assumptions of the HOV model are (Leamer, 1980):

(a) perfect competition in the goods and factors markets,

(b) zero cost of transport of commodities and no other impediments to trade,

(c) immobility of production factors between countries, but complete mobility of production factors between sectors within a country,

(d) identical input-output (technology) relations in all countries,

(e) production functions showing constant returns to scale,

(f) factor price equalization across countries,

(g) equal numbers of factors and goods,

(h) consumers maximize their identical homothetic utility functions.

The following notation will be used:

$\mathrm{T}_{\mathrm{i}}=\mathrm{n} \times 1$ vector of net exports by country $\mathrm{i}$;

$V_{i}=m \times 1$ vector of factor endowments of country $i$;

$V_{w}=\Sigma_{i} V_{i}$ the total world factor endowment vector;

$A=m \times n$ input-output (or technology or factor intensity) matrix with input (or factor) requirements $a_{k j}$ which indicate the amount of factor $k$ used to produce one unit of $\operatorname{good~j;~}{ }^{16}$

$Q_{i}=n \times 1$ vector of goods produced in country $i$;

$Q_{w}=\Sigma_{i} Q_{i}$ the total world production;

$C_{i}=n \times 1$ vector of goods consumed in country $i$;

$\mathrm{P}=\mathrm{n} \times 1$ vector of goods prices;

$Y_{i}=P^{\prime} Q_{i}$ the GDP of country $i$

$Y_{w}=\Sigma_{i} Y_{i}$ the total world GDP;

$B_{i}=P^{\prime} T_{i}$ the trade balance of country $i$.

15. The use of the verb 'tend' indicates that this theorem holds on average (see Deardorff, 1982, and Forstner, 1985).

16. This matrix does not allow intermediate inputs. 
From this it follows (see e.g. Leamer, 1980) that the vector of factors required to produce the vector of outputs $Q_{i}$ is the vector $A Q_{i}$. Due to assumptions (d), (e) and (f), the matrix $A$ is identical for all countries. $A Q_{i}$ also represents the factors embodied in the production of $Q_{i}$. Equilibrium in the factor markets requires that factor demand $A Q_{i}$ is equal to factor supply $V_{i}$, so $A Q_{i}=V_{i}$. The summation of this equation across all countries gives $A Q_{w}=$ $V_{w}$. Because of assumption (a), the vector of goods prices is equal across all countries. $E$ qualization of goods prices and assumption $(\mathrm{h})$ imply that each country i will consume a proportion $\boldsymbol{\beta}_{i}$ of all world-wide produced goods that is the same for all goods. So $C_{i}=\beta_{i} Q_{w}$ holds where $\beta_{i}$ is a scalar. The net exports of country $i$ equal the difference between its production and its consumption, $T_{i}=Q_{i}-C_{i}$. The factors embodied in the net exports are $A T_{i}=A\left(Q_{i}-C_{i}\right)=V_{i}-A \beta_{i} Q_{w}=V_{i}-\beta_{i} V_{w}$. This also implies that $\beta_{i} V_{w}$ indicates the extent to which the world's factor endowments are used by country i's consumption. Formula (1) is the basic equation of this paper and represents the Heckscher-Ohlin-Vanek theorem. A derived form of this equation will be used to estimate the relevance of human capital production factors for trade flows.

$A T_{i}=V_{i}-\beta_{i} V_{w}$

It is easy to derive an intuitively appealing expression for scalar $\boldsymbol{\beta}_{i}$ out of equation (1) (see e.g. Leamer and Bowen, 1981). This can be derived from the expression for the trade balance, which equals the price vector times the volume of net trade vector: $B_{i}=P^{\prime} T_{i}=$ $\mathrm{P}^{\prime} \mathrm{A}^{-1}\left(V_{\mathrm{i}}-\beta_{i} V_{w}\right)=Y_{i}-\beta_{i} Y_{w}$. So $\beta_{i}=\left(Y_{i}-B_{i}\right) / Y_{w}$. This means that $\beta_{i}$ represents the consumption share of country $i$ in total world consumption, corrected for any trade imbalance.

The Heckscher-Ohlin-Vanek theorem states that a country will export the services of abundant production factors and import the services of scarce production factors (Leamer, 1984). Here we have to explain how to define abundant and scarce production factors. The vector $V_{i}$ represents the physical and human capital factor endowments $\left(V_{1 i}, \ldots, V_{k i}, . . V_{m i}\right)^{\prime}$ of country i. Similarly, the vector $V_{w}$ represents the world's factor endowments $\left(V_{1 w}, . ., V_{k w}, . ., V_{m w}\right)^{\prime}$. The quotient of $V_{k i}$ and $V_{k w}$ represents the factor endowment of country $i$ in factor $k$ relative to the world's factor endowment. It is intuitively clear that the right-hand side of formula (1) represents the factor endowments of country $i\left(V_{i}\right)$ corrected for consumption $\left(\beta_{\mathrm{i}} \mathrm{V}_{\mathrm{w}}\right)$. If the right-hand side of formula $(1)$ is positive for factor $k$, i.e. if country $i$ is abundant in factor $k$, then it also holds that $V_{k i} N_{k w}>\beta_{i}$. This result can be used to define factor abundance. Following Leamer (1984), for example, we assume that country $\mathrm{i}$ is abundant in factor $\mathrm{k}$ if its share of the world's supply of factor $\mathrm{k}, \mathrm{V}_{\mathrm{ki}} / N_{\mathrm{kw}}$, exceeds its share of the world's consumption, $\boldsymbol{\beta}_{\mathrm{i}}$, i.e. $\mathrm{V}_{\mathrm{ki}} \mathrm{N}_{\mathrm{kw}}>\boldsymbol{\beta}_{\mathrm{i}}$. 
Following Bowen and Sveikauskas (1992), formula (1) can be corrected for trade imbalances $B_{i}$. Therefore $\beta_{i} V_{w}$ has to be written as $\left(Y_{i}-B_{i}\right) / Y_{w} V_{w}=\left(Y_{i} / Y_{w}\right) V_{w}-\left(B_{i} / Y_{w}\right) V_{w}=a_{i} V_{w}-$ $\left(B_{i} / Y_{w}\right) V_{w}$, where $a_{i}$ is country i's share of world income. When $\left(B_{i} / Y_{w}\right) V_{w}$ is subtracted from each side of formula (1) we get:

$A T_{i}-\left(B_{i} / Y_{w}\right) V_{w}=V_{i}-a_{i} V_{w}$

Because $V_{w}=A Q_{w}$, we can substitute $A Q_{w}$ for $V_{w}$. If $S$ is defined as the $n \times 1$ vector of world shares of each good, $Q_{w} / Y_{w}$, formula (3) results:

$A\left(T_{i}-B_{i} S\right)=V_{i}-a_{i} V_{w}$

Subtracting $B_{i} S$ from $T_{i}$ implies that the excess or deficit for a country's net exports per sector is corrected by $B_{i} S$. The term $B_{i} S$ indicates how the trade imbalance is distributed over the various sectors. If a country's consumption level is too high or too low relative to its income level, the difference is assumed to be distributed over the various sectors according to the share of the production (or consumption, because $Q_{w}=C_{w}$ ) of each good (or sector) on the world market. This follows from the assumption of homothetic utility functions (assumption h).

The critical measure for judging the factor abundance of country $i$ in formula (1) is $\boldsymbol{\beta}_{\mathrm{i}}$, representing country i's share of world consumption. After correcting for trade imbalances, $a_{i}$ replaces $\beta_{i}$ as the critical measure, representing country i's share of world income. Moreover, the larger $V_{k i} N_{k w}$ is, the more abundant country $i$ is in factor $k$. This formalization of factor abundance will be used in the empirical model of section 3 .

If we define $T_{B i}$ as $T_{i}-B_{i} S$, this results in:

$A T_{B i}=V_{i}-a_{i} V_{w}$

Which can be rewritten as:

$\mathrm{T}_{\mathrm{Bi}}=\mathrm{A}^{-1} \mathrm{~V}_{\mathrm{i}}-\mathrm{A}^{-1} \boldsymbol{a}_{\mathrm{i}} \mathrm{V}_{\mathrm{w}}$

Formula (5) indicates that the net exports of country $i$ are dependent on the vector of factor endowments $V_{i}$. The inverse of matrix $A$ only exists if there are equal numbers of 
factors and goods (assumption g). ${ }^{17}$ If there are more sectors (goods) than production factors, it is not possible to determine the trade flows for each sector on theoretical grounds, because the system of equations for country $i$ is under-determined. The inputoutput matrix $A$ is not square and therefore it has no inverse. However, Leamer (1984) states that this is not a cause for concern, because in an empirical analysis the number of goods or sectors depends on the level of aggregation, and the observed production factors are just a selection from a larger set of production factors.

To derive the final equation of this section we have to insert a few more steps. ${ }^{18}$ Recall that $Y_{i}=P^{\prime} Q_{i}, a_{i}=Y_{i} / Y_{w}$ (note that $a_{i}, Y_{i}$ and $Y_{w}$ are scalars) and $V_{w}=A Q_{w}$. From equation (5) it follows that: $T_{B i}=A^{-1} V_{i}-A^{-1} V_{w} a_{i}=A^{-1} V_{i}-A^{-1} A Q_{w} a_{i}=A^{-1} V_{i}-Q_{w} Y_{i} / Y_{w}=A^{-1} V_{i}-$ $Q_{w} P^{\prime} Q_{i} / Y_{w}=A^{-1} V_{i}-Q_{w} P^{\prime} A^{-1} V_{i} / Y_{w}=\left(I-Q_{w} P^{\prime} / Y_{w}\right) A^{-1} V_{i}$, where I represents the identity matrix. Because it is assumed that each sector $j$ produces one good $j$, for sector $j$ of country i we can say for each element of the vector $T_{B i}$ :

$\mathrm{T}_{\mathrm{Bji}}=\sum_{k=1}^{m} \mathrm{~b}_{\mathrm{jk}} \mathrm{V}_{\mathrm{ki}}$

The $b_{j k}$ coefficients of equation (6) represent the matrix $\left(I-Q_{w} P^{\prime} / Y_{w}\right) A^{-1} .^{19}$

Equation (6) clearly shows that the net exports of sector $\mathrm{j}$ in country $\mathrm{i}$ are solely dependent on country's i factor endowments $k$. This equation will be used for developing the empirical model of section 3 .

\section{The empirical model}

As mentioned in the introduction to this paper, our analysis focuses on the relevance of human capital production factors, including technological knowledge. This factor of production can also be partly interpreted as a human capital variable. It seems reasonable to expect differences in human capital investments between countries to have implications for the production and export of goods. Public expenditures on education are a measure for the educational level of the labour force. This would include all kinds of public expen-

17. Furthermore, notice that each row and column of the inverse matrix has to contain both positive and negative elements, since matrix $A$ contains only positive elements.

18. See Leamer (1984) for the two-dimensional case.

19. It follows that these coefficients can be positive as well as negative. 
diture on pre-work education, i.e. at primary, secondary, and tertiary levels. However, the public expenditure measure has the disadvantage of being no more than an input measure for initial schooling efforts. Besides, there is a considerable lag between these educational expenditures and the returns on them. Therefore we prefer an output measure for the educational attainment of the labour force. In order to allow for the different impact of the supply of intermediate skilled 'craft' workers and highly-skilled 'professionals', we distinguish three levels of education, by measuring the shares of low skilled, intermediate skilled and highly-skilled workers in the total workforce of a country (see also e.g. Welch, 1970 and Pencavel, 1991). Besides these human capital factors, it has been argued that technological knowledge is acquired to a large extent by investments in human capital. Furthermore, physical capital remains relevant in the neofactor endowments models. ${ }^{20}$ These models include not only the traditional production factors, of labour and physical capital as in Leontief's studies, but also human capital and technology, as in our study.

However, it is important to scale both net exports per sector and the countries' factor endowments in equation (6). Otherwise the results might be influenced by variations in industry and country size. ${ }^{21}$ To scale the factor endowments we will use the factor abundance definition of section 2 . From the theoretical model presented there, it follows that country $i$ is relatively abundant in factor $k$ if the right-hand side of equation (4) is positive, that is if country's $i$ share of factor $k$ in the world's total factor endowment of factor $\mathrm{k}$ is larger than $a$. As a represents the share of country $\mathrm{i}$ in world income, it follows that country $i$ is abundant in factor $k$ if:

$$
\left(\mathrm{V}_{\mathrm{ki}} / \mathrm{N}_{\mathrm{kw}}\right) /\left(\mathrm{GDP}_{\mathrm{i}} / \mathrm{GDP}_{\mathrm{w}}\right)>1
$$

where

$\mathrm{V}_{\mathrm{ki}} \quad=$ factor endowment of factor $\mathrm{k}$ in country $\mathrm{i}$,

$V_{\mathrm{kw}} \quad=$ factor endowment of factor $\mathrm{k}$ in the world,

$\mathrm{GDP}_{\mathrm{i}}=$ gross domestic product of country $\mathrm{i}$,

$\mathrm{GDP}_{\mathrm{w}}=$ gross domestic product of the world.

As stated before, the larger the left-hand side of (7), the larger the relative factor endowment of country $i$ in factor $k$. Moreover, it follows that the factor endowments of country $i$

20. For overviews see, for example, Deardorff (1984) and Memedovic (1994).

21. On this topic see, for example, Stern (1976) and Memedovic (1994). The latter also gives an overview of the various ways to scale net exports, which result in indicators for revealed comparative advantage. 
are in fact double scaled, viz. first with regard to the total amount of the factor endowment $k$ in the countries in the sample, and second, with regard to the share of country $i$ in the total GDP of the countries in the sample.

Using equation (7), we can calculate the relative factor endowments of the factors of production mentioned before, i.e. labour, human capital, technological knowledge and physical capital. The total factor endowment of the world, and total world income, are both approximated by the sum of the factor endowments of the fourteen countries in the sample and the sum of their GDPs, respectively. This implies that the following relative factor endowments will be calculated: ${ }^{22}$

$\mathrm{LAB}_{\mathrm{i}} \quad=$ the relative factor endowment of labour in country $\mathrm{i}$;

$\mathrm{LSW}_{\mathrm{i}}=$ the relative factor endowment of low skilled workers in country $\mathrm{i}$;

$\mathrm{ISW}_{\mathrm{i}}=$ the relative factor endowment of intermediate skilled workers in country $\mathrm{i}$;

$\mathrm{HSW}_{\mathrm{i}}=$ the relative factor endowment of highly-skilled workers in country $\mathrm{i}$;

$\mathrm{TEC}_{\mathrm{i}} \quad=$ the relative factor endowment of technological knowledge in country $i$;

$\mathrm{CAP}_{\mathrm{i}}=$ the relative factor endowment of physical capital stock in country $\mathrm{i}$.

With regard to the dependent variable, net exports per sector, Minne (1988) proposes double scaling. This implies that the net exports of sector $\mathrm{j}$ are first standardized with regard to total trade by country $i$, and that this ratio is then standardized again according to the proportion of world trade in all sectors which takes place in sector $\mathrm{j}$. The revealed comparative advantage of sector $j$ in country $i$ is shown in the following equation.

$\operatorname{RCA}_{\mathrm{ji}}=\left(\mathrm{T}_{\mathrm{ji}} / \mathrm{U}_{\mathrm{j}}\right) /\left(\mathrm{U}_{\mathrm{jw}} / \mathrm{U}_{\mathrm{w}}\right)$

where

$\mathrm{RCA}_{\mathrm{ji}}=$ the revealed comparative advantage of sector $\mathrm{j}$ in country $\mathrm{i}$;

$\mathrm{T}_{\mathrm{ji}} \quad=$ net exports of sector $\mathrm{j}$ in country $\mathrm{i} ;$

$\mathrm{U}_{\mathrm{ji}}=$ half of the sum of exports and imports of sector $\mathrm{j}$ in country $\mathrm{i}$, to indicate the total trade of the sector if there are no trade imbalances;

$\mathrm{U}_{\mathrm{jw}} \quad=$ half of the sum of world exports and world imports of sector $\mathrm{j}$;

$\mathrm{U}_{\mathrm{w}} \quad=$ half of the sum of total world exports and total world imports.

Equation (8) implies that if exports equal imports for a particular industry, so that intra-

22. Scaling the human capital factor endowments according to equation (7) means that the relative factor endowment of labour, $L A B_{i}$, is a linear combination of the three relative factor endowments of human capital, i.e. $\mathrm{LSW}_{\mathrm{i}}, \mathrm{ISW}_{\mathrm{i}}, \mathrm{HSW}_{\mathrm{i}}$. The weights of the linear combination are equal to the labour supply of workers with the relevant level of education, in the sample, divided by the total labour supply of all workers in the sample. 
industry trade is $100 \%$, the RCA of the industry is zero. ${ }^{23}$

We also have to correct net exports for trade imbalances (see section 2). In appendix B we remark that it is hard to find appropriate data to correct for trade imbalances. For this reason we add the value of a country's trade balance $\left(B_{i}\right)$ to the factor endowment variables on the right side of equation (6). The uncorrected net exports can be used as the dependent variable after double scaling both the trade balance variable and the net exports variable, as in equation (8).

To test the relevance of the various human capital factor endowments with regard to the level of education for the pattern of net trade flows, we will consider two equations. Both equations follow directly from equation (6), although the first equation does not distinguish between the various levels of education, whereas the second equation distinguishes the three skill categories discussed above. ${ }^{24}$

$$
\begin{aligned}
\operatorname{RCA}_{\mathrm{ji}}= & b_{\mathrm{j0}}+b_{\mathrm{j} 1} \text { LAB }_{i} \\
& +b_{\mathrm{j} 5} \text { TEC }_{\mathrm{i}}+\mathrm{b}_{\mathrm{j} 6} \mathrm{CAP}_{\mathrm{i}}+\mathrm{b}_{\mathrm{j} 7} \mathrm{RCA}_{\mathrm{i}}+\mu \\
\mathrm{RCA}_{\mathrm{ji}}= & \mathrm{b}_{\mathrm{j} 0}+\mathrm{b}_{\mathrm{j} 2} \text { LSW }_{\mathrm{i}}+\mathrm{b}_{\mathrm{j} 3} \text { ISW }_{\mathrm{i}}+\mathrm{b}_{\mathrm{j} 4} \mathrm{HSW}_{\mathrm{i}} \\
& +b_{\mathrm{j} 5} \text { TEC }_{\mathrm{i}}+\mathrm{b}_{\mathrm{j} 6} \mathrm{CAP}_{\mathrm{i}}+\mathrm{b}_{\mathrm{j} 7} \mathrm{RCA}_{\mathrm{i}}+\mu
\end{aligned}
$$

where

$\mathrm{RCA}_{\mathrm{i}}=$ the revealed comparative advantage of all sectors of country $\mathrm{i}$ (excluding those belonging to the same labour-intensity category as sector $\mathrm{j}) ;{ }^{25}$

$\mathrm{b}_{\mathrm{jk}} \quad=$ estimated coefficients;

$\mu \quad=$ disturbance term.

Equations (9a) and (9b) are estimated sector-by-sector. Due to assumptions (d) and (e) of section 2, each sector has the same regression coefficient, for a particular relative factor endowment, in all 14 industrialized countries. The HOV theorem states that countries tend to export the services of their abundant factors. By means of the estimation of equations

23. See Minne (1988) for a further discussion of this measure.

24. The constant term $b_{j 0}$ is added to correct for net trade flows between our sample of fourteen countries and the rest of the world.

25. In fact the trade balance variable represents the total of ISIC sectors listed in Appendix A. When calculating the total revealed comparative advantage measure $\left(R C A_{i}\right)$, other the category of economic sectors to which a particular sector belongs is excluded. For example, when calculating the total revealed comparative advantage $R C A_{i}$ of the textile sector (tex), labour-intensive sectors are excluded. 
(9a) and (9b), we can find which sectors are mainly responsible for the export of those factor services. In other words, the estimates of equations (9a) and (9b) show which factor endowments contribute to the success of the export performance of a particular sector.

\section{Hypotheses}

In this section we will develop hypotheses with regard to the consequences of countries' different relative factor endowments for their revealed comparative advantages in four categories of economic sectors with different factor intensities. Our classification of economic sectors is based on OECD (1986), OECD (1987) and Verspagen (1993). According to OECD (1987), economic sectors can be divided into five categories with different factor intensities, i.e., resource-intensive, labour-intensive, scale-intensive, differentiated goods, and science-based sectors. These categories of sectors are assumed to have different factor intensities, so that they can be used to develop hypotheses with regard to the relationship between relative factor endowments and revealed comparative advantages. However, the OECD (1987) admits that it is hard to distinguish the scale-intensive and differentiated goods sectors. Therefore we will classify both kinds of industry in the capital-intensive sector. Moreover, in accordance with the neo-factor endowments theory, we expect that technology will also matter. Therefore we combine the OECD (1987) classification with the classifications of OECD (1986) and Verspagen (1993), which distinguish between low-tech, medium-tech and high-tech sectors. ${ }^{26}$ The resulting classification scheme is shown in appendix $A .{ }^{27}$ We will not test the relationship between the relative factor endowments and the revealed comparative advantages of the resource-intensive sectors, since the trade performance of these sectors is strongly dependent on the abundance of natural resources, which are excluded in our analysis. ${ }^{28}$

Tables $1 \mathrm{a}$ and $1 \mathrm{~b}$ give an overview of the hypotheses that will be tested with regard to the coefficients of the relative factor endowments of equations (9a) and (9b). ${ }^{29}$

26. Since we have only one capital-intensive low-tech sector (i.e. paper and paper products, ISIC 3400 ), our classification will not distinguish between low-tech and medium-tech sectors.

27. Both the science-based sectors distinguished by the OECD (1987) and the 'core-R\&D' sectors distinguished by Verspagen (1993) are here called 'technology-intensive sectors'.

28. As expected, our empirical model does not show any significant results for the resourceintensive sectors.

29. Notice that both matrices of signs contain symmetric properties. 
Table 1a

Hypotheses regarding the coefficients of the relative factor endowments of labour, capital and technological knowledge

\begin{tabular}{lccc} 
Sectors & $\mathrm{LAB}_{\mathrm{i}}$ & $\mathrm{CAP}_{\mathrm{i}}$ & $\mathrm{TEC}_{\mathrm{i}}$ \\
\hline labour-intensive & + & 0 & - \\
capital-intensive, low/medium-tech & $0 /+$ & + & $0 /-$ \\
capital-intensive, high-tech & $0 /-$ & + & $0 /+$ \\
technology-intensive & - & 0 & +
\end{tabular}

With regard to the signs of the estimated coefficients, relative abundances of labour, physical capital and technological knowledge would intuitively be expected to be positively related to revealed comparative advantages in the labour-intensive sectors, the capitalintensive sectors and the technology-intensive sectors, respectively. These expectations are represented by the positive signs of the virtual diagonal running from upper left to lower right of the matrix in table 1a. The other elements of this matrix of signs are not clearly positive or negative, excluding the bottom left-hand corner and the top right-hand corner of the matrix. The latter two negative signs indicate that labour-rich countries are assumed to import technology-intensive goods (i.e. net exports are negative), and technology-rich countries are assumed to import labour-intensive goods. ${ }^{30}$

Table $1 b$

Hypotheses regarding the coefficients of the relative factor endowments of three human capital factors

\begin{tabular}{lccc} 
Sectors & LSW $_{\mathrm{i}}$ & $\mathrm{ISW}_{\mathrm{i}}$ & $\mathrm{HSW}_{\mathrm{i}}$ \\
\hline labour-intensive & + & $\mathrm{O} /-$ & - \\
capital-intensive, low/medium-tech & $0 /+$ & $0 /-$ & $0 /-$ \\
capital-intensive, high-tech & $0 /-$ & $0 /+$ & $0 /+$ \\
technology-intensive & - & $0 /+$ & +
\end{tabular}

30. We find no negative sign in the column for physical capital, as physical capital is expected to be strongly negatively related to the trade performance of service sectors, which are excluded from our analysis. 
Table $1 \mathrm{~b}$ gives an overview of the expected signs of the human capital factor endowments in the four classes of sectors mentioned above.

The expectations with regard to the signs of table $1 \mathrm{~b}$ are based upon two fundamental hypotheses, that is the capital-skill complementarity hypothesis (Griliches, 1969, Hamermesh, 1993) and the technology-skill complementarity hypothesis (e.g. Bartel and Lichtenberg, 1987). ${ }^{31}$ In general we expect that the higher the capital-intensity or the technology-intensity of sectors, the higher the level of human capital that is required. For table $1 \mathrm{~b}$, this implies that the signs in the columns of intermediate and highly-skilled labour increase from the first to the last row, in contrast to the signs in the column for low skilled labour. As we can see from table 1b, applying both the capital-skill and the technology-skill complementarity hypotheses results in clear positive or negative expected signs only for the four corner elements of the matrix. This implies that a relative abundance of low skilled labour is expected to be positively related to revealed comparative advantage of the labour-intensive sectors, and negatively related to revealed comparative advantage of the technology-intensive sectors. Moreover, a relative abundance of highlyskilled labour is expected to be positively related to revealed comparative advantage of technology-intensive sectors and negatively related to revealed comparative advantage of labour-intensive sectors. For the column of intermediate skilled labour, and for the two rows of capital-intensive sectors, the expected signs are less evident.

\section{Data preview}

Table 2 presents the relative factor endowments, which are calculated according to (7). The data sources used to calculate these relative factor endowments are mainly from the OECD and Eurostat, with 1985 as year of reference. ${ }^{32}$ Although the shares of low skilled, intermediate skilled and highly-skilled workers are correlated, this correlation is strongly reduced (see appendix $\mathrm{C}$ ) due to the scaling with equation (8). As stated above, the variable $\mathrm{TEC}_{\mathrm{i}}$, which indicates the level of technological knowledge in a country, is measured by R\&D expenditures and can be regarded as a semi-human capital variable (see also section l). However, to construct a reliable proxy of the level of technological knowledge in a country we also had to take into account that countries buy technological knowledge from abroad, which is expressed by the technological balance-of-payments. These 'imports' of knowledge are not embodied in workers, so that they cannot be

31. See also Wood (1994) on the relationship between, on the one hand, human capital and physical capital and, on the other hand, human capital and technological knowledge.

32. See Appendix B for an extensive list of data sources. 
regarded as human capital. ${ }^{33}$

From table 2 we can see that Portugal, Greece, Spain and Ireland, in particular, have a high relative factor endowment of both labour and low skilled labour. Italy, Great-Britain and Belgium also have an abundance of low skilled labour. On the other hand, the United States, Germany and Canada have a low relative factor endowment of low skilled labour. The relative factor endowment of intermediate skilled labour is high in Germany, Japan and Denmark, and low in almost all other countries, excluding Greece and Ireland. It may be surprising that the latter two countries have an abundance of highly-skilled labour. Canada, the United States and Japan also have a high relative factor endowment of highly-skilled labour, whereas Italy, Germany, Spain and Portugal have low endowments of highly-skilled labour. The relative factor endowment of physical capital is high in Japan, Belgium, Germany, Ireland, the Netherlands, France and Spain, and very low in the United States, Great Britain and Greece. The relative factor endowment of technological knowledge is high in Germany, the United States and Japan, and very low in Greece, Portugal, Spain and Italy.

Table 2

Relative factor endowments per country (1985)

\begin{tabular}{lcccccc}
\hline country & LAB $_{i}$ & LSW $_{i}$ & ISW $_{i}$ & HSW $_{i}$ & TEC $_{i}$ & CAP $_{i}$ \\
\hline Belgium (BEL) & 1.05 & 1.80 & 0.56 & 0.55 & 1.03 & 1.34 \\
Canada (CAN) & 0.91 & 0.75 & 0.78 & 1.37 & 0.61 & 1.06 \\
West Germany (DEU) & 1.08 & 0.87 & 1.77 & 0.33 & 1.15 & 1.22 \\
Denmark (DNK) & 1.23 & 1.33 & 1.32 & 0.90 & 0.59 & 1.07 \\
Spain (ESP) & 1.41 & 2.52 & 0.83 & 0.43 & 0.34 & 1.12 \\
France (FRA) & 1.03 & 1.30 & 1.00 & 0.63 & 0.94 & 1.17 \\
Great Britain (GBR) & 1.24 & 1.87 & 0.80 & 0.86 & 0.97 & 0.79 \\
Greece (GRC) & 1.88 & 3.07 & 1.01 & 1.22 & 0.14 & 0.82 \\
Ireland (IRL) & 1.68 & 2.62 & 0.95 & 1.24 & 1.07 & 1.22 \\
Italy (ITA) & 1.02 & 1.91 & 0.58 & 0.22 & 0.49 & 0.97 \\
Japan (JPN) & 1.27 & 1.12 & 1.53 & 1.10 & 1.10 & 1.67 \\
Netherlands (NLD) & 0.99 & 1.34 & 0.80 & 0.68 & 0.99 & 1.21 \\
Portugal (PRT) & 2.78 & 6.18 & 0.60 & 0.48 & 0.23 & 1.00 \\
United States (USA) & 0.80 & 0.46 & 0.84 & 1.31 & 1.14 & 0.72 \\
& & & & & & \\
\hline
\end{tabular}

Sources and remarks: see appendix B. See appendix $C$ for the correlations between the relative factor endowments. The abbreviations of the countries in the sample are used again in figure 1 below.

33. For the difference between technological knowledge and human capital, see, for example, Romer (1990). 
Now we have given a broad view on the pattern of relative factor endowments across countries, we can compare the relative factor endowments of table 2 with the revealed comparative advantages of figure $1 .^{34}$ However, we will confine ourselves mainly to discussing the most striking results of table 2 and figure 1 , and their relation to the clearest hypotheses (i.e. without the expected zeros) presented in tables $1 \mathrm{a}$ and $1 \mathrm{~b}$.

Figure 1

Revealed comparative advantages by four categories of economic sectors (1985)

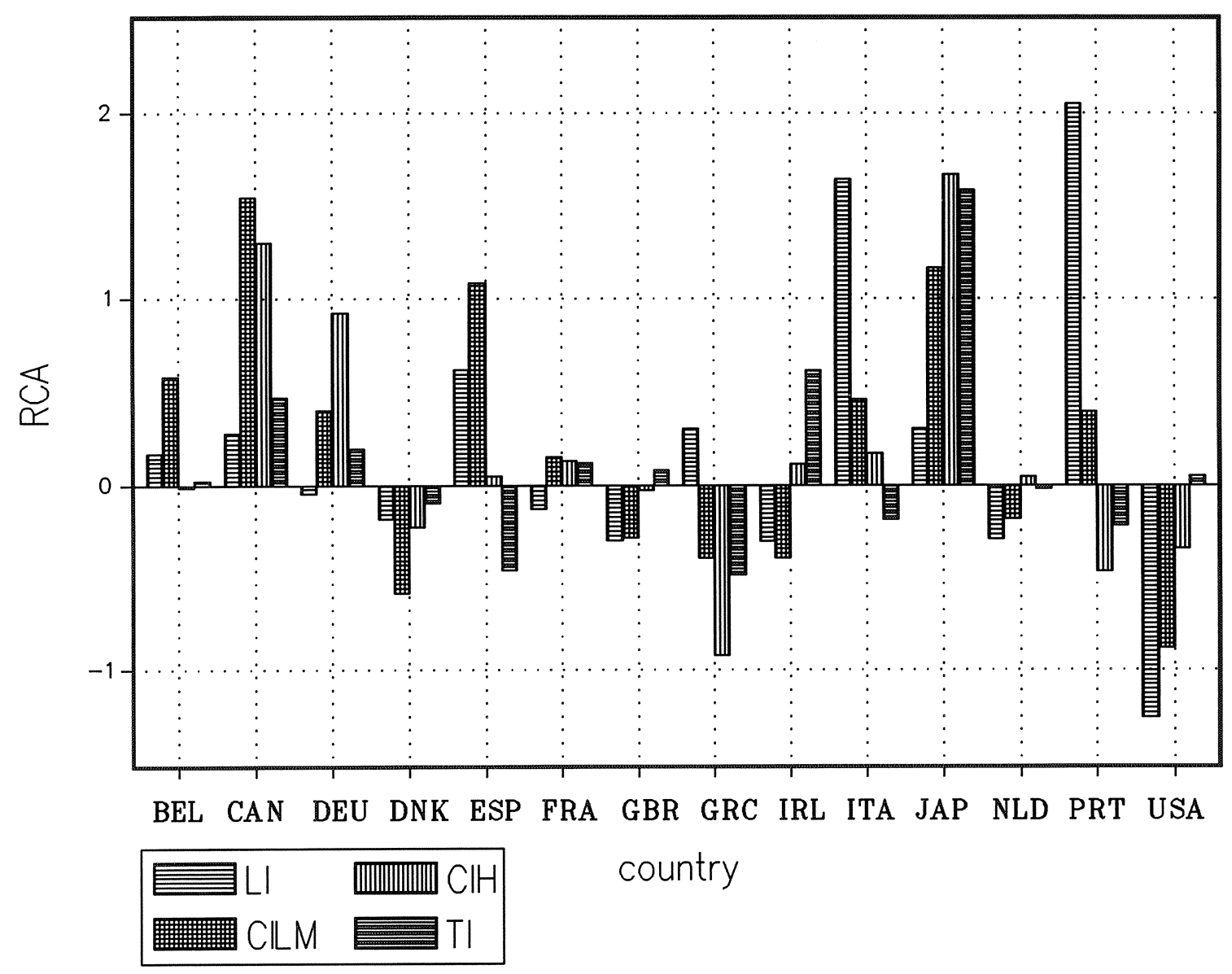

Sources: see appendix B. Note: $\mathrm{LI}, \mathrm{CILM}, \mathrm{CIH}, \mathrm{TI}$ stand for the labour-intensive, capital-intensive low/medium-tech, capital-intensive high-tech and technology-intensive categories of economic sectors, respectively. See table 2 for the abbreviations of the country names.

In accordance with our hypotheses, labour abundant countries and countries which are abundant in low skilled labour, such as Portugal, Greece and Spain, show a revealed comparative advantage in labour-intensive sectors, and a revealed comparative disad-

34. See appendix $D$ for the revealed comparative advantages of the resource-intensive category of economic sectors in these countries. 
vantage in technology-intensive sectors. However, Ireland is an exception on this point, as it has both a large relative factor endowment of low skilled labour and a revealed comparative disadvantage in labour-intensive sectors. Moreover, Ireland has a revealed comparative advantage in the technology-intensive sectors. This may be due to the abundance of highly-skilled labour in Ireland. Furthermore, all countries that have an abundance of technological knowledge have positive revealed comparative advantages in the technology-intensive sectors. On the other hand, France and Great Britain are abundant in neither technological knowledge nor highly-skilled labour, although they have a revealed comparative advantage in the technology-intensive sectors. Canada is abundant only in highly-skilled labour and not in technological knowledge, yet it has a strong revealed comparative advantage in the technology-intensive sectors. As to the relative factor endowments of physical capital, it is evident that countries with low relative factor endowments of physical capital, such as the United States, Great Britain and Greece, have a comparative disadvantage in the capital-intensive sectors. However, there are some exceptions: countries which are abundant in physical capital but do not have revealed comparative advantages in either the low/medium-tech or the high-tech capitalintensive sectors. This may be due to the relevance of the relative factor endowment of technological knowledge for these capital-intensive sectors. Therefore it will be useful to estimate the impact of combinations of relative factor endowments on the revealed comparative advantage of categories of sectors.

\section{Estimation results}

One of the attractive features of the HOV model is that the pattern of relative factor endowments in each country determines the pattern of sectoral net exports from that country. For example, countries that are relatively capital abundant should have a surplus of net exports in the capital-intensive sectors. As has been discussed in section 3, the variables in the model should be scaled properly, resulting in equations (9a) and (9b). By estimating these equations, we can test to what extent the hypotheses formulated in section 4 hold.

Tables $3 a$ and $3 b$ show the results of the OLS regression of the revealed comparative advantages per category of sectors on the relative factor endowments per country, according to equations (9a) and (9b), respectively. ${ }^{35}$

35. As expected, the resource-intensive category of economic sectors, which is excluded from the analysis for the reason mentioned above, revealed very poor results. 
Table 3a

Estimation results for four categories of economic sectors with different factor intensities, excluding human capital factors (equation 9a)

\begin{tabular}{lccccccc}
\hline Category & constant & $\mathrm{LAB}_{\mathrm{i}}$ & $\mathrm{TEC}_{\mathrm{i}}$ & $\mathrm{CAP}_{\mathrm{i}}$ & $\mathrm{RCA}_{\mathrm{i}}$ & $\bar{R}^{2}$ & F-stat \\
\hline LI & -0.45 & 0.36 & -1.57 & 1.27 & -0.03 & 0.47 & $3.84^{\mathrm{b}}$ \\
& $(-0.43)$ & $(0.81)$ & $(-2.49)^{\mathrm{b}}$ & $(1.51)$ & $(-0.07)$ & & \\
CILM & -0.34 & -0.29 & -1.20 & 1.73 & 0.69 & 0.45 & $3.70^{\mathrm{b}}$ \\
& $(-0.37)$ & $(-0.76)$ & $(-2.14)^{\mathrm{a}}$ & $(2.37)^{\mathrm{b}}$ & $(1.62)$ & & \\
CIH & -1.31 & -0.34 & 0.19 & 1.66 & 0.41 & 0.46 & $3.78^{\mathrm{b}}$ \\
& $(-1.50)$ & $(-0.97)$ & $(0.35)$ & $(2.57)^{\mathrm{b}}$ & $(1.23)$ & & \\
TI & -1.74 & 0.21 & 0.79 & 0.91 & 0.25 & 0.48 & $4.05^{\mathrm{b}}$ \\
& $(-2.72)^{\mathrm{b}}$ & $(0.77)$ & $(1.93)^{\mathrm{a}}$ & $(1.73)$ & $(0.87)$ & & \\
\hline
\end{tabular}

Notes:

- $\quad \mathrm{LI}, \mathrm{CILM}, \mathrm{ClH}$, and TI stand for the labour-intensive, capital-intensive low/medium-tech, capitalintensive high-tech and technology-intensive categories of economic sectors, respectively;

- $\quad t$-values between brackets;

- the regressions are carried out with 14 observations, which implies the estimated equation (9a) has 9 degrees of freedom;

- $\quad a=$ significant at $10 \% ; b=$ significant at $5 \% ; c=$ significant at $1 \%$.

The results in table $3 a$, in particular the F-statistics, indicate that the estimated equation (9a) is significant at the $5 \%$ level for these four categories of sectors. Moreover, the signs and the significance of the coefficients of the relative factor endowments generally confirm the hypotheses of table 1a. However, the relative factor endowment of labour does not produce a significant result for any category of economic sectors, which may point to the relevance of distinguishing the various levels of human capital. On the other hand, the coefficient of the technological knowledge variable is, in accordance with our hypotheses, negative and significant for both the labour-intensive and the capital-intensive low/medium-tech economic sectors. The magnitude of the coefficient for the latter category is somewhat smaller, in line with our hypotheses. Furthermore, confirming our hypotheses, the estimated technological knowledge coefficients for the capital-intensive high-tech and the technology-intensive economic sectors are zero, and significantly positive, respectively. Finally, the estimated coefficients for the physical capital variable are only significantly positive for the capital-intensive sectors of industry, which is, again, in accordance with our hypotheses of table 1a. These results generally confirm the value of the HOV model for explaining net trade flows between industrialized countries. 
Table $3 b$

Estimation results for four categories of economic sectors with different factor intensities, including human capital factors (equation $9 \mathrm{~b}$ )

\begin{tabular}{lccccccccc} 
Category & constant & LSW $_{\mathrm{i}}$ & $\mathrm{ISW}_{\mathrm{i}}$ & $\mathrm{HSW}_{\mathrm{i}}$ & $\mathrm{TEC}_{\mathrm{i}}$ & $\mathrm{CAP}_{\mathrm{i}}$ & $\mathrm{RCA}_{\mathrm{i}}$ & $\bar{R}^{2}$ & F-stat \\
\hline \multirow{2}{*}{$\mathrm{LI}$} & 0.64 & 0.21 & -0.24 & -0.79 & -1.19 & 0.87 & 0.30 & 0.68 & $5.61^{\mathrm{b}}$ \\
& $(0.71)$ & $(1.51)$ & $(-0.54)$ & $(-2.16)^{\mathrm{a}}$ & $(-2.35)^{\mathrm{b}}$ & $(1.18)$ & $(0.79)$ & & \\
\multirow{2}{*}{$\mathrm{CILM}$} & 0.03 & -0.10 & -0.33 & -0.36 & -1.05 & 1.67 & 0.77 & 0.37 & 2.27 \\
& $(0.025)$ & $(-0.61)$ & $(-0.62)$ & $(-0.81)$ & $(-1.69)$ & $(1.89)^{\mathrm{a}}$ & $(1.59)$ & & \\
$\mathrm{CIH}$ & -1.49 & -0.13 & 0.44 & -0.04 & 0.11 & 1.36 & 0.52 & 0.42 & 2.59 \\
& $(-1.53)$ & $(-0.88)$ & $(0.84)$ & $(-0.11)$ & $(0.19)$ & $(1.78)$ & $(1.36)$ & & \\
$\mathrm{TI}$ & -2.32 & 0.06 & 0.18 & 0.59 & 0.57 & 1.13 & 0.16 & 0.65 & $5.06^{\mathrm{b}}$ \\
& $(-4.0 .4)^{\mathrm{c}}$ & $(0.69)$ & $(0.63)$ & $(2.53)^{\mathrm{b}}$ & $(1.63)$ & $(2.35)^{\mathrm{b}}$ & $(0.65)$ & &
\end{tabular}

Notes:

- $\mathrm{LI}, \mathrm{CILM}, \mathrm{CIH}$, and TI stand for the labour-intensive, capital-intensive low/medium-tech, capitalintensive high-tech and technology-intensive categories of economic sectors, respectively;

- $\quad \mathrm{t}$-values between brackets;

- the regressions are carried out with 14 observations, which implies that the estimated equation (9b) has 7 degrees of freedom;

- $\quad a=$ significant at $10 \% ; b=$ significant at $5 \% ; c=$ significant at $1 \%$.

Table $3 \mathrm{~b}$ shows the impact of human capital factor endowments on revealed comparative advantages, by estimating equation (9b) instead of equation (9a). It is immediately apparent that the adjusted $R^{2}$ is higher for the labour-intensive and the technologyintensive categories of economic sectors. On the other hand, the adjusted $\mathrm{R}^{2}$ and the significance of the relative factor endowments for the two capital-intensive categories of sectors is lower. The relative factor endowment of highly-skilled workers is, in line with the hypotheses of table $1 \mathrm{~b}$, significantly negatively, and significantly positively, related to the revealed comparative advantages of the labour-intensive and technology-intensive categories of sectors, respectively. However, the relative factor endowment of low skilled labour has, in contrast to what was expected, no significant impact on either the labourintensive or the technology-intensive categories. Moreover, the results for the technologyintensive category of sectors are not exactly as expected, since estimating equation (9b) instead of (9a) reduces the effect of the relative factor endowment of technological knowledge to insignificance, and increases the effect of the relative factor endowment of physical capital to a significant level.

The results of table $3 a$ and $3 b$ indicate that equation $(9 a)$ is to be preferred for the capitalintensive economic sectors, whereas equation $(9 \mathrm{~b})$ is to be preferred for both the labourintensive and technology-intensive sectors of industry. We will take these results into 
account below, in testing at a more disaggregated level, by using equation (9a) for the capital-intensive sectors and equation $(9 \mathrm{~b})$ for the labour-intensive and technologyintensive sectors. Tables $4 a$ and $4 b$ present the results of the respective estimations. ${ }^{36}$

Table 4a

Estimation results for the capital-intensive economic sectors, excluding human capital factors (equation 9a)

Sector constant $\mathrm{LAB}_{\mathrm{i}} \quad \mathrm{TEC}_{\mathrm{i}} \quad \mathrm{CAP}_{\mathrm{i}} \quad \mathrm{RCA}_{\mathrm{i}} \quad \bar{R}^{2} \quad$ F-stat

Capital-intensive, low/medium-tech sectors

$\begin{array}{lccccccc}\text { pap } & 1.41 & 0.36 & -1.12 & -0.80 & 2.64 & 0.50 & 4.24^{\mathrm{b}} \\ & (0.92) & (0.58) & (-1.22) & (-0.66) & (3.75)^{\mathrm{c}} & & \\ \text { rub } & -0.68 & -0.61 & -0.82 & 2.14 & 0.32 & 0.36 & 2.86^{\mathrm{a}} \\ & (-0.62) & (-1.37) & (-0.82) & (2.50)^{\mathrm{b}} & (0.65) & & \\ \text { pla } & 0.25 & -0.58 & -1.74 & 1.67 & 0.28 & 0.44 & 3.52^{\mathrm{b}} \\ & (0.27) & (-1.56) & (-3.19)^{\mathrm{c}} & (2.35)^{\mathrm{b}} & (0.68) & & \\ \text { nme } & 0.06 & -0.03 & -1.72 & 1.66 & -0.34 & 0.50 & 4.20^{\mathrm{b}} \\ & (0.07) & (-0.08) & (-3.11)^{\mathrm{c}} & (2.30)^{\mathrm{b}} & (-0.81) & & \\ \text { bir } & -1.99 & -0.76 & -0.99 & 3.70 & -0.29 & 0.50 & 4.29^{\mathrm{b}} \\ & (-1.61) & (-1.50) & (-1.33) & (3.79)^{\mathrm{c}} & (-0.51) & & \end{array}$

Capital-intensive, high-tech sectors

$\begin{array}{cccccccc}\text { ich } & -0.43 & -0.21 & 1.07 & -0.02 & 0.53 & 0.75 & 10.61^{\mathrm{c}} \\ & (-0.91) & (-1.11) & (3.56)^{\mathrm{c}} & (-0.04) & (2.94)^{\mathrm{b}} & & \\ \text { mac } & -0.98 & -0.22 & 0.58 & 0.90 & 0.03 & 0.27 & 2.21 \\ & (-1.13) & (-0.61) & (1.06) & (1.40) & (0.08) & & \\ \text { ele } & -1.47 & -0.37 & -0.27 & 2.06 & -0.24 & 0.49 & 4.11^{\mathrm{b}} \\ & (-1.90)^{\mathrm{c}} & (-1.18) & (-0.54) & (3.60)^{\mathrm{c}} & (-0.81) & & \\ \text { tra } & -2.03 & -0.52 & -0.51 & 3.13 & 0.84 & 0.45 & 3.62^{\mathrm{b}} \\ & (-1.41) & (-0.88) & (-0.55) & (2.93)^{\mathrm{b}} & (1.51) & & \end{array}$

Notes:

- see appendix A for the abbreviations of the sectors;

- $\quad t$-values between brackets;

- the regressions are carried out with 14 observations, which implies the estimated equation (9a) has 9 degrees of freedom;

- $\quad a=$ significant at $10 \% ; b=$ significant at $5 \% ; c=$ significant at $1 \%$.

36. Once again, all resource-intensive sectors revealed very poor results, as expected. 
Table $4 b$

Estimation results for the labour-intensive and technology-intensive economic sectors, including human capital factors (equation $9 \mathrm{~b}$ )

Sector constant LSW $_{\mathrm{i}} \quad \mathrm{ISW}_{\mathrm{i}} \quad \mathrm{HSW}_{\mathrm{i}} \quad \mathrm{TEC}_{\mathrm{i}} \quad \mathrm{CAP}_{\mathrm{i}} \mathrm{RCA}_{\mathrm{i}} \quad \overline{\boldsymbol{R}}^{2} \quad$ F-stat

Labour-intensive sectors

tex

$0.74 \quad 0.39$

$0.39-0.43$

$-0.75-1.59$

0.88

0.17

0.81

$10.36^{c}$

$(0.75)$

$(2.57)^{\mathrm{b}}(-0.90)$

$(-1.87)^{\mathrm{a}}(-2.86)^{\mathrm{b}}$

(1.09)

(0.41)

pme

$\begin{array}{ccccc}0.58 & -0.11 & 0.24 & -0.89 & -0.58 \\ (0.63) & (-0.76) & (0.55) & (-2.39)^{\mathrm{b}} & (-1.12)\end{array}$

0.77

0.46

0.37

2.28

oma

$\begin{array}{ccccccc}0.36 & 0.05 & -0.28 & -0.78 & -0.70 & 0.97 & 0.53 \\ (0.28) & (0.27) & (-0.45) & (-1.50) & (-0.98) & (0.93) & (0.96)\end{array}$

0.12

1.29

Technology-intensive sectors

$\begin{array}{lccccccccc}\text { och } & -0.50 & -0.05 & 0.03 & -0.18 & 1.09 & 0.02 & 0.29 & 0.74 & 7.01^{\mathrm{c}} \\ & (-1.03) & (-0.63) & (0.18) & (-0.94) & (3.70)^{\mathrm{c}} & (0.05) & (1.39) & & \\ \text { off } & -3.45 & 0.27 & -0.00 & 1.35 & 1.23 & 0.91 & 0.16 & 0.35 & 2.15 \\ & (-2.79)^{\mathrm{b}} & (1.42) & (-0.00) & (2.67)^{\mathrm{b}} & (1.63) & (0.88) & (0.30) & & \\ \text { rad } & -4.58 & 0.04 & 0.52 & 0.70 & -0.53 & 3.63 & 0.10 & 0.50 & 3.17^{\mathrm{a}} \\ & (-3.22)^{\mathrm{b}} & (0.16) & (0.72) & (1.21) & (-0.62) & (3.06)^{\mathrm{b}} & (0.16) & & \\ \text { air } & 1.94 & -0.08 & -0.47 & 0.11 & 0.77 & -1.69 & 0.08 & 0.43 & 2.65 \\ & (2.33)^{\mathrm{b}} & (-0.65) & (-1.12) & (0.32) & (1.51) & (-2.44)^{\mathrm{b}} & (0.23) & & \\ \text { opt } & -2.16 & 0.07 & 0.62 & 0.63 & 1.12 & 0.18 & 0.22 & 0.78 & 8.60^{\mathrm{c}} \\ & (-3.99)^{\mathrm{c}} & (0.83) & (2.27)^{\mathrm{a}} & (2.84)^{\mathrm{b}} & (3.40)^{\mathrm{c}} & (0.40) & (0.94) & & \end{array}$

Notes:

- see appendix A for the abbreviations of the sectors;

- $t$-values between brackets;

- the regressions are carried out with 14 observations, which implies that the estimated equation (9b) has 7 degrees of freedom;

- $a=$ significant at $10 \% ; b=$ significant at $5 \% ; c=$ significant at $1 \%$.

All estimated equations presented are significant, except for the machinery sector (mac). The results of the capital-intensive economic sectors are in accordance with the hypotheses of table $1 \mathrm{a}$ as far as the significant coefficients are concerned, although the estimation results of the paper sector (pap) are not adequately explained by the relative factor endowments. For six of the nine capital-intensive economic sectors, the coefficient of relative factor endowment of physical capital is significantly positive, as expected. Also in accordance with the hypotheses of table $1 \mathrm{a}$, the coefficients for the low/medium-tech 
category are significantly negative for both the plastics (pla) and the non-metallic minerals (nme) sectors, while the coefficients for the high-tech category are significantly positive only for the industrial chemicals (ich) economic sector. However, the fact that most coefficients cannot be rejected against the null-hypothesis does not contradict the hypotheses of table 1a. Next we present the results for the labour-intensive and technology-intensive economic sectors.

The estimation results presented in table $4 b$ reveal very strong results only for the textile sector (tex), the other chemicals sector (och) and the optical sector (opt). Interpreting the results of the labour-intensive economic sectors, we can conclude that the signs of the significant regression coefficients are in accordance with the hypotheses of tables $1 \mathrm{a}$ and 1b. In particular, the regression of the textile sector (tex) performs remarkably well, and in lire with our hypotheses for the relative factor endowments of low skilled labour, highlyskilled labour and technological knowledge. Moreover, the metal products sector (pme) reveals, as expected, a significantly negative coefficient for the relative factor endowment of highly-skilled labour. On the other hand, the sector of other manufacturing industries (oma) shows a poor result, which may be due to the fact that it is a heterogeneous residual sector.

The technology-intensive economic sectors reveal, in accordance with our hypotheses, the importance of technological knowledge and human capital in three out of five cases. The optical sector (opt) is the only economic sector for which an abundance of intermediate skilled labour seems to matter. The significant results for the relative factor endowment of physical capital in the radio and television sector (rad) and the aircraft sector (air) are not in line with our hypotheses and cannot easily be explained. Moreover, relative abundance of low skilled labour does not have the expected negative effect on revealed comparative advantage in the technology-intensive economic sectors.

\section{Conclusions}

The empirical results generally confirm the value of the HOV model (and the related neofactor endowments model) for explaining net trade flows between industrialized countries. The empirical results suggest that it is worthwhile to consider relative factor abundancies at the country level to explain revealed comparative advantages, which are a measure of trade performance, at sector level. Therefore the HOV model is an adequate framework for testing the relevance of human capital factors for the trade performance of sectors. In line with our hypotheses, the human capital factor endowments of countries seem to have a significantly positive impact on the revealed comparative advantage of technology- 
intensive economic sectors, and a significantly negative impact on the revealed comparative advantage of labour-intensive sectors. For capital-intensive sectors, human capital factor endowments were not found to have a significant effect. But technological knowledge has a significantly negative effect on the revealed comparative advantage of capital-intensive low/medium-tech economic sectors, which is according to our expectations. Moreover, the availability of highly-skilled workers seems to have at least as great an impact as access to technological knowledge on the trade performance of technologyintensive economic sectors.

The relatively good empirical results in this paper are, in our opinion, to a large extent due to the correct specification of the model, the method of double scaling, and the use of data of industrialized countries, which are probably more equal in their input-output coefficients than a mixed group of both industrialized and developing countries. Three further points should be noted with regard to the specification of the empirical model. First, the specification of the model follows directly from the theoretical exposition of the HOV model of section 2. Second, as has been argued in section I, the human capital factor endowments should be measured by the level of education of the workforce rather than by occupational categories. Like Wood (1994), we believe that the fact that human capital was measured using occupational categories may account for the relatively poor results of human capital factor endowments in e.g. Leamer (1984). Third, we do not agree with Wood that the international mobility of financial capital flows means that the factor endowment of physical capital should be excluded from the model. Our empirical analysis shows that both human and physical capital factor endowments are important for the trade performance of economic sectors.

The suggested country-specificity of human capital, technological knowledge and physical capital may be due to differing national educational systems, government technology policies and differing national capital investment climates, respectively. Nevertheless, the results also indicate that country-specific relative factor endowments cannot explain more than about $50 \%$ to $80 \%$ of the variances in revealed comparative advantages at sector level. This may be due to measurement errors or some violations of the assumptions of the model. Moreover, the unexplained variance may plausibly be accounted for by sectoral developments and clusters of economic sectors (as explained by Porter, 1990).

\section{References}

Baldwin, R.E. (1971), Determinants of the Commodity Structure of U.S. Trade, American Economic Review, Vol. 61, pp. 126-146. 
Bartel, A.P. and F.R. Lichtenberg (1987), The Comparative Advantage of Educated Workers in Implementing New Technology, Review of Economics and Statistics, Vol. 69, pp. 1-11.

Bowen, H.P., E.E. Leamer and L. Sveikauskas (1987), Multicountry, Multifactor Tests of the Factor Abundance Theory, American Economic Review, Vol. 77, pp. 791-809.

Bowen, H.P. and L. Sveikauskas (1992), Judging Factor Abundance, Quarterly Journal of Economics, Vol. 107, pp. 599-620.

Branson, W.H. and N. Monoyios (1977), Factor Inputs in U.S. Trade, Journal of International Economics, Vol. 7, pp. 111-131.

Brecher, R.A. and E.U. Choudhri (1982), The Factor Content of International Trade Without Factor Price Equalization, Journal of International Economics, Vol. 12, pp. 277283.

Campbell, A. and M. Warner (1991), Training Strategies and Microelectronics in the Engineering Industries of the UK and Germany; in P. Ryan (ed.), International Comparisons of Vocational Education and Training for Intermediate Skills, The Falmer Press, Loncion.

Daly, A. (1986), Education and Productivity: A Comparison of Great Britain and the United States, British Journal of Industrial Relations, Vol. 24, pp. 251-266.

Daniels. P. (1993), Research and Development, Human Capital and Trade Performance in Technology-intensive Manufactures: A Cross-country Analysis, Research Policy, Vol. 22, pp. 207-241.

Deardorff, A.V. (1982), The General Validity of the Heckscher-Ohlin Theorem, American Economic Review, Vol. 72, pp. 683-94.

Deardorff, A.V. (1984), Testing Trade Theories and Predicting Trade Flows; in R.W. Jones and P.B. Kenen (eds), Handbook of International Economics, Vol. 1, Elsevier, Amsterdam.

Dosi, G., K. Pavitt and L. Soete (1990), The Economics of Technical Change and International Trade, Harvester Wheatsheaf, New York etc.

Ethier, W.J. (1982), National and International Returns to Scale in the Modern Theory of International Trade, American Economic Review, Vol. 72, pp. 950-959.

Forstner, H. (1985), A Note on the General Validity of the Heckscher-Ohlin Theorem, American Economic Review, Vol. 75, pp. 844-849.

Griliches, Z. (1969), Capital-Skill Complementarity, Review of Economics and Statistics, Vol. 51, pp. 465-486.

Hamermesh, D.S. (1993), Labor Demand, Princeton University Press.

Helpman, E. (1981), International Trade in the Presence of Product Differentiation, Economies of Scale and Monopolistic Competition, A Chamberlain-Heckscher-Ohlin Approach, Journal of International Economics, Vol. 11, pp. 305-340.

Helpman, E. (1984), The Factor Content of Foreign Trade, Economic Journal, Vol. 94, pp. 84-94.

Keesing, D.B. (1966), Labor Skills and Comparative Advantage, American Economic Review, Proceedings, Vol. 56, pp. 249-258.

Keesing, D.B. (1968), Labor Skills and the Structure of Trade in Manufactures; in P. 
Kenen and R. Lawrence (eds), The Open Economy: Essays on International Trade and Finance, New York, pp. 3-18.

Krugman P.R. and M. Obstfeld (1991), International Economics, Theory and Policy, second edition, Harper Collins, New York.

Leamer, E.E. (1980), The Leontief Paradox Reconsidered, Journal of Political Economy, Vol. 88, pp. 495-503.

Leamer, E.E. (1984), Sources of International Comparative Advantage, Theory and Evidence, MIT Press, Cambridge, Massachusetts.

Leamer, E.E. (1992), Testing Trade Theory, NBER, Working Paper No. 3957.

Leamer, E.E. and H.P. Bowen (1981), Cross-section of the Heckscher-Ohlin Theorem: Comment, American Economic Review, Vol. 71, pp. 1040-1043.

Leontief, W.W. (1953), Domestic Production and Foreign Trade: The American Capital Position Re-examined, Proceedings of the American Philosophical Society, Vol. 93, pp. 332-349.

Leontief, W.IV. (1956), Factor Proportions and the Structure of American Trade: Further Theoretical and Empirical Analysis, Review of Economics and Statistics, Vol. 38, pp. 386-407.

Lindley, R.M. (1991), Interactions in the Markets for Education, Training and Labour: A European Perspective on Intermediate Skills; in P. Ryan (ed.), International Comparisons of Vocational Education and Training for Intermediate Skills, The Falmer Press, London.

Lucas, R.E.B. (1988), On the Mechanisms of Economic Development, Journal of Monetary Economics, Vol. 22, pp. 3-42.

Maddison, A. (1991), Dynamic Forces in Capitalist Development, Oxford University Press, New York.

Memedovic, O. (1994), On the Theory and Measurement of Comparative Advantage. An Empirical Analysis of Yugoslav Trade in Manufactures with the OECD countries, 19701986, Tinbergen Institute Research Series No. 65, Thesis Publishers, Amsterdam.

Minne, B. (1988), Links between the International Pattern of Specialisation in Manufactured Goods, Factor Intensities and Growth Rates, Research Memorandum No. 45, Central Planning Bureau, The Hague.

OECD (1986), R\&D, Invention and Competitiveness, Science and Technology Indicators, No. 2.

OECD (1987), Structural Adjustment and Economic Performance, Paris.

Pencavel, J. (1991), Higher Education, Productivity, and Earnings: A Review, Journal of Economic Education, Vol. 22, pp. 331-359.

Porter, M.E. (1990), The Competitive Advantage of Nations, The Free Press, New York.

Prais, S.J. (1981), Vocational Qualifications of the Labour Force in Britain and Germany, National Institute Economic Review, November, pp. 47-59.

Romer, P.M. (1990), Endogenous Technological Change, Journal of Political Economy, Vol. 94, pp. 1002-1037.

Stern, R.M. (1976), Some Evidence on the Factor Content of West Germany's Foreign 
Trade, Journal of Political Economy, Vol. 84, pp. 131-141.

Stern, R.M. and K.E. Maskus (1981), Determinants of the Structure of U.S. Foreign Trade, Journal of International Economics, Vol. 11, pp. 207-224.

Vanek, J. (1968), The Factor Proportions Theory: The N-Factor Case, Kyklos, Vol. 21, pp. 749-754.

Verspagen, B. (1993), R\&D and Productivity, A broad cross-section cross-country look, Research Memorandum No. 7, MERIT, Maastricht.

Waehrer, H. (1968), Wage Rates, Labor Skills, and United States Foreign Trade; in P. Kenen and R. Lawrence (eds), The Open Economy: Essays on International Trade and Finance, New York, pp. 19-39.

Welch, F. (1970), Education in production, Journal of Political Economy, Vol. 78, pp. 35-59.

Wood, A. (1994), Give Heckscher and Ohlin a Chance!, Weltwirtschaftliches Archiv, Vol. 130 , pp. $20-49$. 



\section{Appendix A Classification of ISIC sectors}

The abbreviations and the ISIC codes of the various economic sectors are as follows:

1. Resource-intensive sectors

agr 1000 Agriculture, hunting, forestry and fishing

min $2000 \quad$ Mining and quarrying

foo 3100 Food, beverages and tobacco

woo 3300 Wood and wood products, including furniture

pet 3530 Petroleum refineries

coa 3540 Miscellaneous products of petroleum and coal

bme $3720 \quad$ Non-ferrous metal basic industries

\section{Labour-intensive sectors}

tex 3200 Textile, wearing apparel and leather industries

pme 3810 Fabricated metal products, except machinery and equipment

oma 3900 Other manufacturing industries

3. Capital-intensive, low/medium-tech sectors

pap $3400 \quad$ Paper and paper products, printing and publishing

rub $3550 \quad$ Rubber products

pla $3560 \quad$ Plastic products not classified elsewhere

nme $3600 \quad$ Non-metallic mineral products, except products of petroleum and coal

bir $3710 \quad$ Iron and steel basic industries

\section{Capital-intensive, high-tech sectors}

ich $3510 \quad$ Industrial chemicals

mac 3820 Machinery except electrical, and excluding sector 3825 (off)

ele 3830 Electrical machinery apparatus, appliances and supplies, excluding sector 3832 (rad)

tra $3840 \quad$ Transport equipment, excluding sector 3845 (air)

\section{Technology-intensive sectors}

och 3520 Other chemical products

off 3825 Office, computing and accounting machinery

rad 3832 Radio, television and communication equipment and apparatus

air $3845 \quad$ Aircraft

opt 3850 Professional, scientific, measuring, controlling equipment not classified elsewhere, photographic and optical goods 



\section{Appendix B Data sources}

This section briefly discusses the available data with regard to net exports per sector $\left(T_{j i}\right)$ and the human capital and other factor endowment variables $\left(\mathrm{V}_{\mathrm{ki}}\right)$ used in the HOV model presented in section 2 (before scaling). Unless stated otherwise, the reference year for the data used is 1985 .

\section{Net exports}

The data for net exports per sector $j$ of country $i\left(T_{j i}\right)$ was drawn from the OECD's COMTAP database. We had data available for economic sectors at the two, three, and four-digit level of the International Standard Industrial Classification (ISIC, revision 2). As it is hard to find appropriate data on volumes of net trade, which is required by the HOV model, we regard values of net trade as a proxy for the volumes. All net export values are expressed in terms of 1985 dollars (in thousands of dollars). In section 2 we pointed to the relevance of correcting the net exports per sector to allow for the country's trade imbalance. To correct for trade imbalances in the proper way we have to know the share of the production of each good in total world production (compare $\mathrm{Qw} / \mathrm{Yw}$ of section 2). As we had no proper data available on these proportion we corrected for trade imbalances by adding, after double scaling, an overall trade balance variable to the independent factor endowment variables on the right-hand side of equations (7a) and (7b). We will refer to a country's overall trade balance as the sum of its net sector exports from agriculture (ISIC 1000), mining (ISIC 2000) and manufacturing (ISIC 3000), minus the net exports of the category of sectors which the economic sector being considered belongs to (see section 3).

\section{Labour supply}

The labour supply variable indicates the amount of labour available in a country. The Eurostat Labour Force Survey (1985) data is used for the various EC countries. This data is supplemented by the data from the Year Book of Labour Statistics (various issues) of the International Labour Office (ILO) for Canada, Japan and the United States. There are some minor differences in the definitions used in the two data sources, but these differences are not significant. The indicators for the labour supply available from Eurostat and the ILO are the 'labour force' and the 'economically active population', respectively.

\section{Educational attainment}

The human capital variables are distinguished by the educational attainment or "educational stock" of the population. A related indicator proposed by the OECD (1989) is the 
distribution of the population over the levels of educational attainment, ranging from $A$ (low) to $E$ (high). ${ }^{37}$ This distribution over levels of education is to a certain extent analogous to UNESCO's International Standard Classification for Education (ISCED). In particular, the ISCED levels $0 / 1$ (pre-primary and primary education as highest achieved level) and 2 (lower secondary education as highest achieved level) correspond with the OECD definition of level $A$. Level $A$ is defined as "completed less than upper secondary education" (OECD, 1989), which corresponds with "completed less than ISCED level 3". This level of education is called low skilled in our paper. The 'highly-skilled' workers in the paper correspond to either level $D$ (higher non-university education) or level $E$ (university education) in the OECD classification. We take the proportion of the population aged 25 to 64 years who completed an initial education beyond lower secondary education (ISCED level 2), but without achieving level D or E, as a proxy for the share of intermediate skilled workers in the labour force. This implies that workers with vocational education are counted as intermediate skilled workers. The data is drawn from the OECD's (1989) Employment Outlook, and (1992) Education at a Glance, and UNESCO's (1992) Statistical Yearbook. The latter source is only used to obtain figures for Greece.

The reference year for the educational data is 1987, except for Belgium (1986), Denmark (1988), France (1989), Ireland (1989), Greece (mean of 1981 and 1991) and the United States (1988). However, we do not expect that these differences between reference years will cause serious problems, since the educational attainment of an entire labour force does not generally change very much in the course of a few years.

\section{Technological knowledge}

The technology variable indicates the stock of technological knowledge of a country. We would prefer to use the total research and development (R\&D) staff of a country as a proxy for a country's stock of technological knowledge. Unfortunately, comparable data of this proxy is not available for all countries. Therefore we take another proxy for which data is available: the research and development (R\&D) intensity. The R\&D intensity is the R\&D expenditures of both the government and the private sector, plus payments for imports of technological knowledge, divided by the gross domestic product. These expenditures are also expressed in millions of 1985 dollars. For Portugal the mean of the 1984 and 1986 R\&D expenditures was used. For Ireland the only figure available for imports of technological knowledge was for 1983. The fact that R\&D expenditures instead of R\&D stocks are used is, to our opinion, no serious shortcoming since both R\&D intensities and import intensities of technological knowledge are relatively constant over time. See the OECD's

37. Level $C$ is not part of the rank order $A$ to $E$, it indicates only that a person has vocational skills at some level. 
Basic Science and Technology Statistics and Main Science and Technology Indicators, from which the data was drawn.

\section{Capital stock}

The physical capital variable indicates the capital stock of a country. The capital stock measure equals the accumulated, depreciated sum of past gross domestic investments in producer durables, nonresidential construction and other construction. This capital stock measure is expressed in 1985 purchasing power parities, in millions of dollars. Data is drawn from Maddison (1991) and the OECD's Penn World Table, mark 5. The first source is only used for the Netherlands. Because there is no appropriate data available on the Portuguese capital stock, the Portuguese capital intensity (i.e. capital stock divided by labour supply) has been estimated using the GDP per worker and the R\&D intensity. 



\section{Appendix C Correlations between relative factor endowments}

Table 5 presents the correlations between the relative factor endowments of table 2 .

Table 5

Correlations between the relative factor endowments

\begin{tabular}{|c|c|c|c|c|c|c|}
\hline & $\mathrm{LAB}_{\mathrm{i}}$ & LSW $_{i}$ & $\mathrm{ISW}_{\mathrm{i}}$ & $\mathrm{HSW}_{\mathrm{i}}$ & TEC $_{i}$ & $\mathrm{CAP}_{\mathrm{i}}$ \\
\hline $\begin{array}{l}\operatorname{LAB}_{i} \\
\text { LSW }_{i} \\
I^{S} W_{i} \\
\mathrm{HSW}_{i} \\
\text { TEC }_{i} \\
\text { CAP }_{i}\end{array}$ & 1.00 & $\begin{array}{l}0.96 \\
1.00\end{array}$ & $\begin{array}{r}-0.15 \\
-0.38 \\
1.00\end{array}$ & $\begin{array}{r}-0.08 \\
-0.25 \\
0.09 \\
1.00\end{array}$ & $\begin{array}{r}-0.59 \\
-0.64 \\
0.34 \\
0.14 \\
1.00\end{array}$ & $\begin{array}{r}-0.10 \\
-0.17 \\
0.42 \\
-0.14 \\
0.39 \\
1.00\end{array}$ \\
\hline
\end{tabular}

Sources and iemarks: see section 5 . Correlation coefficients are significant at $10 \%$ if they are larger than 0.46 or smaller than -0.46 .

From table 5 it follows that only the correlations between $\mathrm{LAB}_{i}, \mathrm{LSW}_{\mathrm{i}}$ and $\mathrm{TEC}_{\mathrm{i}}$ are significant, which may reduce the significance of these variables in the OLS estimation of section 6 . 



\section{Appendix D RCAs of the resource-intensive category of economic sectors}

Figure 2 presents the revealed comparative advantages of the resource-intensive category of sectors in the fourteen industrialized countries of our sample.

\section{Figure 2}

Revealed comparative advantages of the resource-intensive category of economic sectors (RI)

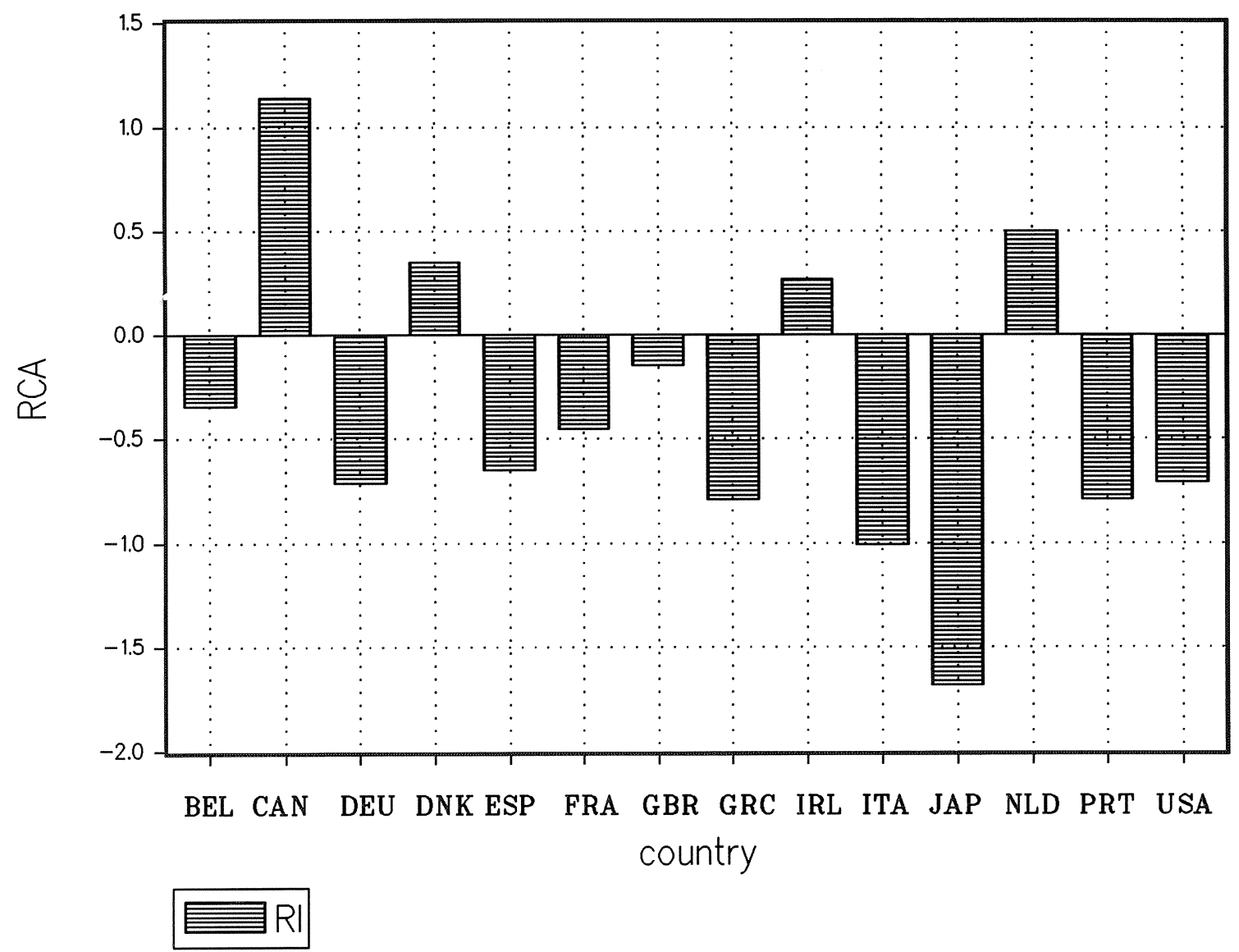

Sources: see appendix B. See table 2 for the abbreviations of the country names.

From figure 2 it can be seen that only Canada, Denmark, Ireland and the Netherlands have a comparative advantage in the resource-intensive category of economic sectors. As would be expected, Japan has a strong comparative disadvantage in this category of economic sectors. 
